\title{
Ouvidoria e cultura organizacional
}

\author{
Ombudsmanship, listening and organizational culture \\ Defensoría y cultura organizzcional
}

Neiva Renck Maciel ${ }^{1}$

Quando iniciamos a ouvidoria do Ministério da Previdência Social, éramos praticamente a única ouvidoria em ministérios. Hoje temos aproximadamente, só em Brasília, mais de cem ouvidorias públicas, o que significa um despertar da administração pública para a participação democrática do cidadão nos destinos do País.

Essa experiência tem sido exitosa e tende a se multiplicar, porém é de fundamental importância que a ouvidoria possa ser exercida com autonomia. Por isso, o ouvidor não pode estar submetido a nenhuma pressão política. O papel dele é de intermediação, ou seja, de promover a comunicação entre o público e o órgão no qual trabalha. Nesse papel de mediador, ele só realiza sua função quando consegue resolver as questões que legitimamente o povo reclama.

Assim, como articulador nesse processo de comunicação, o ouvidor precisa ter um cuidado especial nas relações internas que mantém com os demais setores de sua organização, seja costurando vínculos, seja promovendo novas interações, sob pena de não obter sucesso diante do público que representa.

Por isso, o ouvidor não é apenas aquele que representa o público, o cidadão. É também aquele que promove a interação da organização consigo mesma, exercendo, desse modo, o papel de agente de mudança e de integração cultural.

1 Advogada, foi ouvidora do Ministério da Previdência Social e é ouvidora-geral do Ministério da Integração Nacional do Brasil. 